\title{
EKSPLORASI AKTIVITAS ETNOMATEMATIKA DI PASAR TRADISIONAL NOEMUTI KABUPATEN TIMOR TENGAH UTARA (TTU)
}

\author{
Dominikus Kou ${ }^{1 *}$, Selestina Nahak ${ }^{2}$, Oktovianus Mamoh ${ }^{3}$ \\ 1,2,3 Universitas Timor \\ *dominikuskou@gmail.com
}

Diterima: 23 Mei 2021. Disetujui: 03 Maret 2021. Dipublikasikan: 31 Juli 2021

\begin{abstract}
ABSTRAK
Matematika dan budaya merupakan dua hal yang memiliki keterkaitan yang sangat erat. Keterkaitan antara matematika dan budaya dikenal dengan istilah etnomatematika. Etnomatematika merupakan matematika yang tumbuh dan berkembang dalam budaya. Dengan menerapkannya etnomatematika sebagai suatu pendekatan pembelajaran, wawasan siswa akan semakin luas dan juga siswa akan lebih mudah dalam mempelajari matematika karena langsung terkait dengan budaya yang merupakan aktivitas mereka sehari - hari. Penelitian ini bertujuan untuk untuk mendeskripsikan aktivitas etnomatematika di Pasar Tradisional Noemuti Kabupaten Timor Tengah Utara. Teknik pengumpulan data dalam penelitian ini dilakukan dengan observasi, wawancara dan dokumentasi. Teknik analisis data dalam penelitian ini dilakukan dengan analisis domain, analisis taksonomi, analisis komponensial, dan analisis tema budaya. Hasil penelitian menunjukan bahwa terdapat konsep - konsep matematika pada aktivitas di Pasar Tradisional Noemuti Kabupaten Timor Tengah Utara antara lain: konsep himpunan, aritmetika sosial, persamaan linear, penjumlahan, pengurangan, perkalian, pembagian, diskon, bilangan kardinal serta prinsip matematika yaitu prinsip perbandingan yang dapat diimplementasikan kedalam pembelajaran matematika di sekolah dalam bentuk pembuatan soal-soal matematika. Oleh karena itu peneliti menyarankan agar guru dapat menjadikan hasil eksplorasi aktivitas etnomatematika di Pasar Tradisioal Noemuti Kabupaten Timor Tengah Utara sebagai penerapan pembelajaran matematika kontekstual.
\end{abstract}

Kata kunci: Aktivitas, Etnomatematika, Pasar Tradisional Noemuti.

\begin{abstract}
Mathematics and culture are two things that are very closely related. The relationship between mathematics and culture is known as ethnomathematics. Ethnomathematics is mathematics that grows and develops in culture. By applying ethnomathematics as ea learning approach, students insight will be broader and students will also find it easier to learn mathematics because it is directly related to the culture wich is their daily activities. This study aims to discribe the ethnomathematical activity in the Noemuti Traditional Market, Nort Central Timor Regerency. Data collection techniques in this study were carried out by observation, interviews and documentation. The data analysis technique used in this research is domain analysis, taxonomic analysis, component analysis, and cultural theme analysis. The result show that the are mathematical consepts in the activities in the Noemuti Traditional Market, Nort Central Timor Regerency including: the concept of set, division, addition, subtraction, multiplication, dicount, cardinal numbers and mathematical principles, namely the principle of comparison and linear equations which can be implemented into mathematics learning in schools in the form of making math problems. Therefore, researchers suggest that teachers can use the results of exploration of ethnomatematic activities in the Noemuti Traditional Market, Nort Central Timor Regerency as an application of contextual mathematics learning.
\end{abstract}

Keywords: Activity, Ethnomatematics, Noemuti Traditional Market.

\section{Pendahuluan}

Matematika dan budaya merupakan dua hal yang memiliki keterkaitan yang sangat erat, karena matematika merupakan ilmu yang digunakan untuk menyelesaikan masalah dalam kehidupan sehari hari sedangkan budaya merupakan kebiasaan - kebiasaan yang dihayati dan dihidupi oleh masyarakat di 


\section{Range: Jurnal Pendidikan Matematika Vol. 3 No. 1 Tahun 2021 Dominikus Kou dkk}

tempat dan daerah tertentu sebagai satu pedoman dalam hidup bersama. Matematika juga merupakan bagian dari aktivitas manusia yang menciptakan kebudayaan, sedangkan kebudayaan diartikan sebagai bagian dari aktivitas masyarakat yang melibatkan unsur - unsur matematika sebagai sarana dan aktualisasi diri. Matematika terwujud karena adanya aktivitas manusia (Angriani, 2013). Sedangkan budaya terwujud karena adanya rangkaian dari aktivitas manusia yang berpola dan diturunkan secara turun temurun. Keterkaitan antara matematika dan budaya dikenal dengan isitilah etnomatematika.

Secara harafiah etnomatematika terdiri atas dua kata yakni etno (etnis/ budaya) dan matematika. Istilah etnomatematika ini pertama kali diperkenalkan oleh seorang matematikawan Brasil yaitu Urbitan D'Ambrosio pada tahun 1977. Menurut D'Ambrosio etnomatematika secara bahasa terbentuk dari kata ethno, mathema, dan tics. Awalan "ethno" diartikan sebagai sesuatu yang luas yang mengacu pada konteks sosial budaya, termasuk bahasa, kode perilaku, mitos dan simbol, sedangkan " mathema" memiliki arti menjelaskan, mengetahui, memahami, dan melakukan kegiatan seperti pengkodean, mengukur, mengklasifikasi, menyimpulkan, dan pemodelan, dan akhiran "tics" diartikan sebagai teknik. Sedangkan etnomatematika secara istilah menurut D'Ambrosio diartikan sebagai "The mathematics wich is pacticed among identifiable cultural groups such as national tribe societies, labour groups, children of certain age breckets and professional classes" (D'Ambrosio, 1985). Artinya matematika yang dipraktekkan di berbagai kelompok budaya seperti masyarakat suku bangsa, kelompok pekerja, anak anak kelompok usia tertentu, dan kelompok profesional. Gagasan D' Ambrosio tersebut menjelaskan bahwa etnomatematika muncul karena akibat dari matematika yang dipengaruhi oleh budaya. Lebih lanjut dijelaskan oleh D'Ambrosio (Supriadi, Arysetyawan \& Tiurlina, 2016) bahwa etnomatematika juga merupakan sebuah pendekatan pengajaran dan pembelajaran matematika yang dibangun berdasarkan latar belakang siswa dan pengalaman masa lalunya serta lingkungan sekarang. Penggunaan etnomatematika sebagai suatu pendekatan pembelajaran justru sangat memungkinkan siswa untuk lebih paham dengan materi yang diajarkan karena langsung terkait dengan budaya yang merupakan aktivitas mereka sehari hari.

Selain itu juga menurut Kencanawati dan Irawan (Suwarsono, 2019) etnomatematika merupakan cara - cara tertentu yang dipergunakan oleh suatu masyarakat atau kelompok budaya dalam aktivitas matematika. Dimana aktivitas matematika adalah aktivitas yang didalamnya terjadi proses pengabstraksian dari pengalaman nyata dalam kehidupan sehari - hari kedalam matematika ataupun sebaliknya, meliputi aktivitas mengelompokkan, berhitung, membilang, dan sebagainya. Aktivitas aktivitas ini muncul dari ide - ide yang secara alami dilakukan oleh masyarakat, melalui pengetahuan dan pandangan suku atau kelompok masyarakat tertentu atau individu tertentu tanpa melalui suatu pendidikan atau pelatihan formal. Dengan demikian maka dapat disimpulkan bahwa etnomatematika merupakan matematika yang tumbuh dan berkembang dalam budaya. Hal ini berarti bahwa konsep matematika dapat digali dan ditemukan dalam budaya yang ada disekitar siswa sehingga dapat dimanfaatkan sebagai sumber belajar yang konkret.

Berdasarkan kajian tersebut, maka kurikulum matematika sekolah harusnya selaras dengan bentuk - bentuk budaya, sehingga dapat memfasilitasi siswa untuk mendapatkan pengetahuan, pemahaman, dan menyelaraskan pengetahuan dan pemahamannya dengan praktik - praktik budaya yang memang sudah sangat dikenal oleh mereka sebelumnya (Turmudi, 2017). Pendapat ini bersesuaian dengan kebijakan pemerintah tentang pemberlakuan kurikulum di Indonesia pada saat ini yakni kurikulum 2013.

Kurikulum 2013 merupakan sebuah kurikulum yang terintegrasi dengan dua program besar dari pemerintah yakni Penguatan Pendidikan Karakter (PPK) dan Gerakan Literasi Sekolah (GLS). Penguatan Pendidikan Karakter dalam kurikulum 2013 dapat di integrasikan dalam seluruh pembelajaran (Amsikan \& Nahak, 2017) yang berkaitan dengan norma atau nilai - nilai pada setiap bidang studi yakni dengan cara mengaitkan materi pembelajaran dengan konteks kehidupan sehari - hari. Sedangkan Gerakan Literasi Sekolah merupakan kemampuan mengakses, memahami, dan menggunakan sesuatu secara cerdas melalui berbagai aktivitas antara lain membaca, melihat, menyimak, menulis dan berbicara. Gerakan Literasi Sekolah ini dapat terintegrasi dalam pembelajaran di kelas yakni dimulai dari penyusunan 


\section{Range: Jurnal Pendidikan Matematika Vol. 3 No. 1 Tahun 2021 Dominikus Kou dkk}

Rencana Pelaksanaan Pembelajaran (RPP). Penyusunan RPP mengakomodasi seluruh waktu pembelajaran baik itu tahap pendahuluan, kegiatan inti maupun kegiatan penutup. Oleh sebab itu agar pembelajaran bernuansa literatif maka diperlukan berbagai sumber dan media pembelajaran. Sumber belajar tidak hanya berasal dari guru, tetapi lingkungan sekitar juga dapat menjadi sumber belajar.

Namun pada kenyataanya, pembelajaran matematika di sekolah sering disajikan terlalu formal dan masih jauh berbeda dengan apa yang ditemukan siswa dalam kehidupan sehari - hari. Hal ini disebabkan karena metode yang digunakan oleh guru dalam pembelajaran di kelas adalah metode ceramah yang selalu berpusat pada buku referensi yang konteksnya masih jauh dari pengalaman siswa. Metode ini justru menjadi salah satu penyebab siswa kurang terlibat aktif dalam proses belajar mengajar karena siswa kurang diberi kesempatan untuk bekerja sama dalam suatu kelompok sehingga kreativitas siswa kurang berkembang karena tidak terbiasa untuk berdiskusi dengan teman kelompoknya dalam menyelesaikan suatu permasalahan. Padahal, banyak siswa sebenarnya punya kemampuan matematika yang cukup tinggi, namun karena guru kurang memberi stimulus kepada siswa dan juga kurang memberikan kesempatan kepada siswa untuk menyampaikan refleksi hasil belajar, akibatnya siswa merasa bosan dan malas dalam mengikuti pembelajaran matematika sehingga timbul sebuah konsep dalam ruang lingkup siswa bahwa matematika itu merupakan sebuah ilmu yang sulit, membosankan, banyak rumus dan tidak berguna.

Berdasarkan uraian permasalahan tersebut, maka pembelajaran matematika perlu dikaitkan dengan budaya sekitar sehingga wawasan siswa akan semakin luas dan juga siswa akan lebih mudah dalam mempelajari matematika karena langsung terkait dengan budaya yang merupakan aktivitas mereka sehari - hari. Salah satu caranya adalah dengan mengeksplorasikan aktivitas matematika yang dilakukan oleh para pedagang di Pasar Tradisional Noemuti Kabupaten Timor Tengah Utara. Aktivitas matematika yang dimaksud adalah aktivitas matematika yang terdapat pada proses pengemasan barang, penentuan harga jual, serta interaksi sosial. Aktivitas matematika ini dipengaruhi oleh budaya sehingga disebut sebagai aktivitas etnomatematika.

Beberapa macam aktivitas etnomatematika yang ditemukan di Pasar Tradisional Noemuti tersebut belum pernah digunakan dalam pembelajaran di kelas sebagai salah satu bentuk pembelajaran kontekstual, oleh sebab itu aktivitas etnomatematika yang terdapat di Pasar Tradisional Noemuti tersebut menjadi fokus dalam penelitian ini sehingga nilai - nilai matematika ataupun konsep - konsep matematika yang terkandung dapat di eksplorasikan dan dijadikan sebagai salah satu bentuk bahan pembelajaran yang kontekstual berbasir Pasar Tradisional Matematika.

Hasil eksplorasi dari penelitian ini dapat dijadikan sebagai dasar pengembangan bahan pembelajaran matematika kontekstual berbasis pasar tradisional Noemuti Kabupaten Timor Tengah Utara.

\section{Metode Penelitian}

Jenis penelitian yang digunakan adalah penelitian kualitatif dengan menggunakan pendekatan etnografi. Penelitian ini dilaksanakan di Pasar Tradisional Noemuti Kabupaten Timor Tengah Utara . Subyek dalam penelitian ini adalah para pedagang di Pasar Tadisional Noemuti. Obyek dalam penelitian ini adalahaktivitas pedagang di Pasar Tradisional Noemuti Kabupaten Timor Tengah Utara. Teknik pengumpulan data dilakukan dengan obsevasi, wawancara dan dokumentasi. Teknik analisis data dalam penelitian ini terdiri dari analisis domain, analisis taksonomi, analisis komponensial, dan analisis tema budaya.

\section{Hasil Penelitian dan Pembahasan}

Berdasarkan hasil observasi peneliti menemukan beberapa aktivitas yang dilakukan oleh para pedagang pada Pasar Tradisional Noemuti Kabupaten Timor Tengah Utara yakni cara pengemasan barang, penentuan harga jual, dan interaksi sosial sebagai berikut: 


\section{Range: Jurnal Pendidikan Matematika Vol. 3 No. 1 Tahun 2021 Dominikus Kou dkk}

1. Cara Pengemasan Barang

Cara pengemasan barang merupakan suatu teknik dimana para pedagang mempersiapkan barang dagangan sebelum melakukan transaksi jual beli. Berdasarkan hasil wawancara dengan subjek S1 diketahui bahwa cara mengemas barang - barang dagangan sebelum mulai berjualan adalah dengan meperhatikan jenis barang tersebut. Setiap barang yang memiliki kesamaan jenis akan dikumpulkan. Barang - barang yang diperdagangkan oleh subjek S1 adalah sayur - sayuran dan bumbu - bumbuan. Jenis sayuran yang diperdagangkan oleh Subjek S1 antara lain sayur putih, tomat, terong, lombok dan kangkung sedangkan jenis bumbu - bumbuan yang diperdagangkan adalah pala, lada, kunyit, lengkuas, serai dan asam. Berikut cuplikan wawancara peneliti dengan subjek S1 terkait cara pengemasan barang dagangan.

$P \quad$ :"Bagaimana cara ibu mengemas sayur sayuran dan bumbu - bumbuan sebelum berjualan?"

S1 :"Sebelum saya mulai berjualan awalnya saya kemas sayurannya dulu, nah pengemasannya disesuaikan dengan jenisnya. Contohnya sayur putih saya ikat lalu tumpuk tersendiri, terong saya tumpuk tersendiri tersendiri, begitu juga dengan bumbu - bumbuannya."

$P \quad$ :"Kenapa ibu tidak campur misalnya sayur putih dicampur dengan kangkung, tomat dicampur dengan lombok atau kunyit dicampur dengan serai?"

S1 :"Saya tidak campur karena biasanya orang beli sesuai dengan minatnya. Kalau misalnya dia hanya minat sayur putih sendiri maka dia akan membeli sayur putih saja tanpa ada campuran sayur lainnya begitupun sebaliknya kalau pembeli minatnya bumbu - bumbuan saja maka ia akan beli bumbu - bumbuan saja tanpa campur dengan sayuran."

$P \quad$ :"Kira - kira berapa jumlah setiap jenis sayuran dalam satu tumpukkan? Maksud saya adalah berapa jumlah tomat, lombok, dan terong dalam satu tumpukkan serta sayur putih dan kangkung dalam satu ikat?"

S1 :"Untuk sayur putih satu ikat isinya 9-10 pohon, kangkung $45-50$ pohon, sedangkan tomat untuk yang buah kecil biasanya 28 - 30 buah sedangkan yang buah besar 10 buah, lombok 70 - 80 buah dalam satu tumpukkan, dan terong biasanya cuman 5 buah saja

Berdasarkan cuplikan wawancara di atas diketahui bahwa pengemasan sayur putih dan sayur kangkung dilakukan dengan cara diikat lalu ditumpukkan pada sebuah terpal sebagai alasnya. Banyaknya sayur putih setiap ikatan dalam tumpukkan tersebut berkisar antara $9-10$ pohon, sedangkan sayur kangkung berkisar antara 45-50 pohon. Cara pengemasan sayur putih dan sayur kangkung seperti pada gambar berikut.

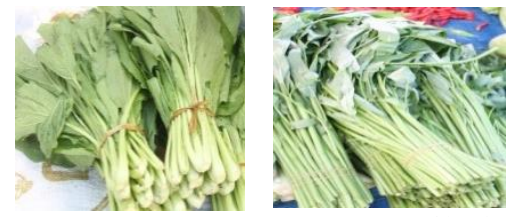

Gambar 1. Cara Pengemasan Sayur putih dan kangkung

Selain pengemasan di atas, ada pengemasan sayuran lainnya seperti terong, tomat, dan lombok yang juga dilakukan dengan cara menumpuk langsung pada alas terpal yang sudah disediakan. Banyaknya terong dalam satu tumpukkan 5 buah, sedangkan tomat berkisar antara $28-30$ buah dalam satu tumpukkan yang berukuran kecil dan untuk yang berukuran besar berjumlah 10 buah, sedangkan lombok berkisar antara 70-80 buah dalam satu tumpukkan. Berikut cara pengemasan sayur terong, tomat, dan lombok.
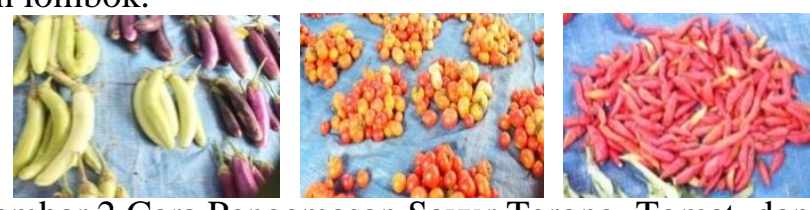

Gambar 2.Cara Pengemasan Sayur Terong, Tomat, dan Lombok 


\section{Range: Jurnal Pendidikan Matematika Vol. 3 No. 1 Tahun 2021 Dominikus Kou dkk}

Selain pengemasan sayuran di atas, pengemasan bumbu juga dilakukan dengan cara menumpuk berdasarkan jenisnya. Berikut cara pengemasan bumbuan.

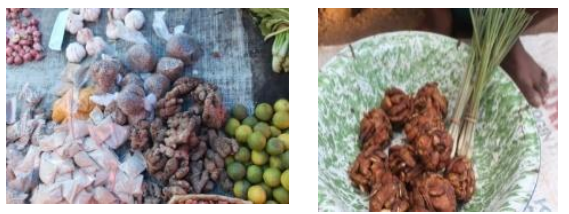

Gambar 3. Cara Pengemasan Bumbuan

Berdasarkan gambar tersebut diketahui bahwa cara pengemasan barang yang dilakukan oleh subjek S2, S3 dan S4 sama halnya dengan cara pengemasan barang yang dilakukan oleh subjek S1 yakni selalu bedasarkan jenisnya. Jenis dagangan subjek S2 adalah ikan. Berikut cuplikan wawancara peneliti dengan subjek S2.

$P \quad$ :"Bagaimana cara bapak mengemas ikan - ikan ini sebelum dijual supaya bisa menarik minat pembeli?"

S2 :"Ya sebelum mulai berjualan ikan yang kita bawa kita susun terlebih dahulu di atas box sesuai dengan jenisnya. Contohnya ikan tembang kita susun sendiri, ikan kombong kita susun sendiri, setelah itu kita siram terus biar kelihatannya segar terus sehingga pembeli bisa tertarik untuk membeli."

$P \quad$ :"Kira - kira berapa jumlah ikan yang bapak kemas dalam satu tumpuk?

S2 :"Jumlah ikan tembang dalam satu tumpuk adalah 10 ekor sedangkan ikan kombong berjumlah 7ekor untuk yang berukuran kecil dan 3 ekor untuk yang berukuran besar."

Berdasarkan cuplikan wawancara di atas, diketahui bahwa banyaknya ikan dalam satu tumpukkan tergantung pada jenis ikan. Jika jenis ikan yang diperdagangkan adalah ikan tembang, maka banyaknya ikan tembang dalam satu tumpukkan adalah 10 ekor, jika yang diperdagangkan adalah ikan kombong maka banyaknya ikan kombong tersebut dalam satu tumpukkan adalah 7 ekor untuk yang berukuran kecil dan 4 ekor untuk yang berukuran besar. Berikut cara pengemasan ikan oleh subjek S2.

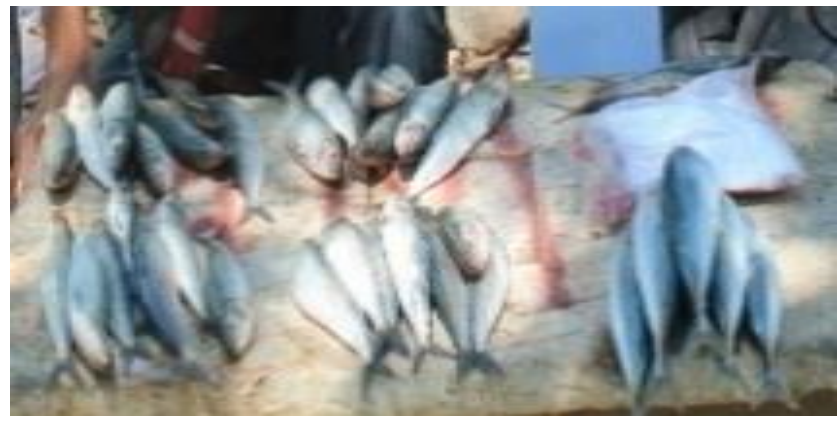

Gambar 4. Cara Pengemasan Ikan

Sedangkan jenis dagangan subjek S3 adalah pakaian. Cara pengemasan pakaian oleh subjek S3 adalah dengan menumpuk dan menggantung pada palang bambu yang sudah disediakan. Cara penumpukkan dan penggantungan pakaian selalu berdasarkan jenisnya. Berikut cuplikan wawancara peneliti dengan subjek S3.

$P \quad$ :"Bagaimana cara Mas mengemas pakaian sebelum mulai berjualan?"

S3 :"Cara kemasnya seperti biasa, baju kita simpan sendiri, celana kita simpan sendiri, jacket kita simpan sendiri, kain sarung kita simpan sendiri dan lain sebagainya. Jadi kita tidak bisa simpan gabung, ini mempermudah kami supaya saat pembeli datang untuk membeli maka dengan mudah untuk kita layani."

Berdasarkan cuplikan wawancara tersebut diketahui bahwa cara pengemasan barang oleh subjek S3 dilakukan dengan dua cara yakni digantung dan ditumpuk. Proses penggantungan dan penumpukkan selalu berdasarkan jenisnya. Berikut cara pengemasan barang oleh subjek S3. 


\section{Range: Jurnal Pendidikan Matematika Vol. 3 No. 1 Tahun 2021 Dominikus Kou dkk}

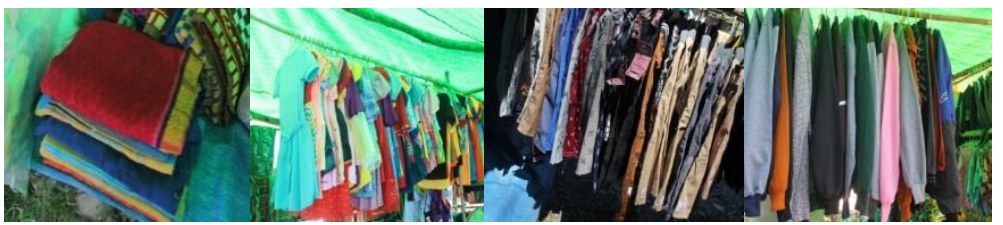

Gambar 5. Cara Pengemasan Pakaian

Selain pengemasan di atas, ada pengemasan barang dagangan lain yang dilakukan oleh subjek S4 dengan cara menumpuk berdasarkan jenisnya. Jenis barang yang diperdagangkan oleh subjek S4 adalah Sirih, pinang, kapur sirih dan tembakau. Berikut cara pengtemasan sirih pinang, kapur sirih dan tembakau.

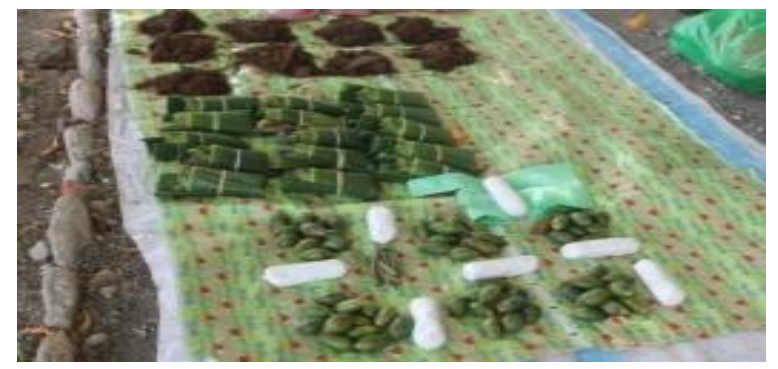

Gambar 6. Cara Pengemasan Sirih, Pinang, Kapur sirih, Tembakau.

2. Penentuan harga jual

Penentuan harga jual merupakan hal yang paling penting karena dapat menentukan besarnya pendapatan yang akan diterima. Harga jual merupakan nilai dari suatu produk yang dipertukarkan konsumen untuk memanfaatkan produk tersebut. Berdasarkan keterangan dari subjek S1 diketahui bahwa penentuan harga jual sayuran dilihat dari kondisi harga pasaran saat itu sebab pada dasarnya penetapan harga jual dilakukan dengan cara menghitung terlebih dahulu biaya produksi (modal) kemudian ditambahkan dengan keuntungan yang diinginkannya. Berikut cuplikan wawancara peneliti dengan subjek S1.

$P \quad$ :"Bagaimana cara penentuan harga sayur - sayuran dan bumbu - bumbuan yang akan ibu jual?

S1 :'Tergantung jenis sayuran dan jenis bumbuannya.. Tetapi biasanya kita tentukan harga barang itu kita usahakan supaya merata dengan penjual lainnya. Contohnya sayur putih satu ikat Rp 5.000 ya semua penjual sayur putih juga sama.

$P \quad$ :"Apa pengaruh penentuan harga terhadap keuntungan penjualan sayur - sayuran dan bumbu - bumbuan ini?

S1 :"Kita tentukan harga sayur - sayuran dan bumbu - bumbuan biasanya kita sudah hitung dengan keuntungannya. Karena sayuran ini bukan hasil produksi sendiri, maka keuntungan dari penjualan sayuran ini sudah kami perhitungkan pada saat menentukan haga jual.

$P \quad$ :"Oh jadi sayuran ini ibu beli dari produsen baru dijual kembali?"

S1 :"'Iya, ibu biasanya ofer dari petani baru dijual kembali kecuali bumbu - bumbuan yang ibu jual ini merupakan hasil produksi sendiri"

$P \quad$ :"sayuran yang dibeli dari petani dihitung per ikat atau borongan?"

S1 :"Biasanya kita beli di Petani itu sistim borong dan sistim ikat tergantung dari produsennya, setelah itu baru kita bagi kembali untuk dijual"

$P \quad$ :"Bagaimana cara ibu membaginya?"

S1 :"Saya contohkan misalnya saya borong sayur putih satu bedeng pada produsen dengan harga Rp 100.000. Untuk mengetahui berapa jumlah ikat sayur yang dapat saya peroleh dari hasil borong tersebut maka saya mulai adakan perhitungan dengan cara bagi total keseluruhan sayur putih dalam satu bedeng dengan banyaknya jumlah pohon dalam satu ikat sayur putih supaya kita bisa tahu kira - kira satu bedeng sayur yang saya beli terdiri 


\section{Range: Jurnal Pendidikan Matematika Vol. 3 No. 1 Tahun 2021 Dominikus Kou dkk}

dari berapa ikat sayur putih. Dari situlah kita bisa hitung keuntungan penjualnnya. Sedangkan untuk memperoleh keuntungan pembelian sayur secara ikat, saya kurangkan jumlah sayuran dalam setiap ikatan lalu dijual kembali dengan harga yang sama. Contohnya apabila saya membeli 1 ikat sayur putih pada produsen dengan harga $R p 5.000$ yang isinya 15 pohon, maka saya jual kembali dengan harga yang sama tetapi isinya dikurangi menjadi 10 pohon. Jika yang saya beli adalah sayur kangkung dengan harga $R p 5000$ dan isinya berkisar antara 60 - 70 pohon maka saya jual kembali dengan harga $R p 5.000$ per ikat tetapi isinya saya kurangi menjadi $40-50$, cara ini berlaku sama pada penjualan terong yakni apabila harga pembelian pada produsen adalah $R p 5.000$ per 7 buah maka saya jual kembali dengan harga yang sama tetapi isinya saya kurangi menjadi 5 buah, sedangkan pada penjualan tomat dan lombok, saya gunakan sistem takar dengan tangan saya yakni dengan mengambil beberapa genggam untuk ditata di atas terpal membentuk suatu tumpukkan dengan isinya berkisar antara antara $28-30$ buah untuk tomat dan lombok berkisar antara 70 - 80 buah dalam satu tumpukkan yang dijual dengan harga $R p$ 5.000/ tumpuk.

Berdasarkan hasil wawancara tersebut diketahui bahwa keuntungan yang diperoleh subjek S1 sudah terhitung pada saat penentuan harga jual. Misalnya harga pembelian 1 ikat sayur putih pada produsen oleh subjek S1 dengan isinya 15 pohon adalah $R p 5.000$, maka subjek S1 menjual kembali dengan harga yang sama tetapi isinya dikurangi menjadi 10 pohon dalam satu ikat. Hal yang sama terjadi pada penjualan sayuran lainnya. Pada penjualan terong, subjek S1 menjelaskan bahwa harga pembelian pada produsen $R p 5.000$ per 7 buah dijual kembali dengan harga $R p 5.000$ per 5 buah. Sedangkan pada penjualan sayur kangkung, subjek S1 menjelaskan bahwa harga pembelian 1 ikat sayur kangkung pada produsen adalah $R p 5.000$ per ikat dengan isinya berkisar antara $60-70$ pohon dijual kembali dengan harga yang sama tetapi isinya dikurangi menjadi $40-50$ pohon. Serta pada penjualan tomat dan lombok, subjek S1 menggunakan sistem takar dengan tangannya yakni dengan mengambil beberapa genggam untuk ditata di atas terpal membentuk suatu tumpukkan dengan isinya berkisar antara $28-30$ buah untuk tomat dan lombok berkisar antara $70-80$ buah dalam satu tumpukkan yang dijual dengan harga $R p$ 5.000/ tumpuk. Sedangkan harga jual bumbu bumbuan selain serai dan asam adalah $R p 5.000 /$ bungkus. Harga serai adalah $R p 2.000 / i k a t$. Harga ini dapat berubah jika ada kesepakatan pemberian diskon dalam proses tawar menawar sehingga Subjek S1 dapat menjual serai dengan harga $R p 5.000 / 3$ ikat. Hal yang sama terjadi pada penjualan asam, subjek S1 dapat menjual asam dengan harga $R p 5.000 / 3$ molak jika terjadi suatu kesepakatan dalam pro2ses tawar menawar.

Selain cara penentuan harga di atas, ada cara penentuan harga lainnya oleh subjek S3 dan S4 yang juga dilakukan dengan menghitung terlebih dahulu jumlah biaya produksi (modal) dengan keuntungan yang diinginkan. Berikut hasil wawancara peneliti dengan Subjek S3 terkait penentuan harga jual.

$P \quad:$ :Bagaimana caranya Mas menentukan harga pakainannya"

S3 :"Penentuan harga pakaian saya lakukan dengan cara menghitung terlebih dahulu biaya produksi (modal) ditambah dengan keuntungan yang saya inginkan serta perkiraan harga tawar oleh pembeli sehingga dalam proses tawar menawar nanti harga jual suatu pakain yang disepakati sudah terhitung modal dan keuntungan.

Sedangkan berdasarkan hasil wawancara dengan subjek S2 yang merupakan seorang pedagang ikan diketahui bahwa subjek S2 hanyalah seorang agen yang mempunyai tugas untuk menjual barang dagangan dengan harga jual yang sudah ditentukan oleh distributornya. Berikut cuplikan wawancara peneliti dengan subjek S2.

$P \quad$ :"Bagaimana cara bapak menentukan harga ikan?"

S2 :"Ikan yang kami jual ini bos sudah tentukan memang harga jualnya jadi kami hanya jual sesuai harga tersebut. Kami kan nanti dihitung premi dari penjualan ini. Contohnya kalau 


\section{Range: Jurnal Pendidikan Matematika Vol. 3 No. 1 Tahun 2021 Dominikus Kou dkk}

kami bawa ikan dengan total harganya Rp 1.000 .000 maka kami dikasih premi $20 \%$ dari total harga tersebut."

$P \quad$ :"Apa bapak tau dari mana bos mendapatkan stok ikan?"

S2 :"'Ikan yang kami jual ini bos beli langsung dari Nelayan di Kupang. Harga pembelian ikan paling mahal satu box itu Rp 1.200.000. Setelah itu baru bos bagi lagi untuk dijual kembali dalam bentuk ekor"

3. Interaksi Sosial

Interaksi sosial merupakan hubungan antara individu dengan individu, individu dengan kelompok, kelompok dengan kelompok. Salah satu contoh interaksi sosial pada Pasar Tradisional Noemuti adalah interaksi antara pedagang dengan konsumen (Pembeli). Interaksi ini dapat dilihat pada transaksi jual beli khususnya pada proses tawar menawar barang sebelum terjadi suatu kesepakatan. Proses tawar menawar ini selalu berpuncak pada pemberian diskon.

Diskon merupakan upaya pemotongan harga yang diberikan kepada pembeli pada saat melakukan pembelian suatu barang. Ada dua jenis diskon yang biasanya dilakukan oleh para pedagang di Pasar Tradisional Noemuti yakni diskon harga dan diskon barang. Diskon harga biasanya dilakukan oleh pedagang pakaian, dimana para pedagang memberikan potongan harga kepada pembeli pada saat melakukan pembelian suatu barang sedangkan diskon barang biasanya dilakukan oleh pedagang ikan dan pedagang bumbu dimana para pedagang menambahkan jumlah barang kepada konsumen dari satuan kemasan yang sudah ditetapkan. Berikut cuplikan wawancara peneliti dengan pedagang pakaian (Subjek S2).

$P \quad$ :"Mas kira - kira harga pakaian yang ditentukan diberikan diskon tidak?"

S2 :"Diskon itu ada tetapi selalu melekat pada kesepakatan dalam proses tawar - menawar."

$P \quad$ :"Berarti besarnya diskon tidak ada tetapan?"

S2 :"Iya, tergantung pada kesepakat dengan pembeli dalam proses tawar menawar tersebut."

Berdasarkan hasil wawancara tersebut diketahui bahwa diskon harga yang diberikan oleh subjek S2 kepada pembeli selalu berdasarkan kesepakatan dalam proses tawar menawar.

Selain pemberian diskon, dalam proses transaksi jual beli para pedagang memanfaatkan operasi hitung pada bilangan yakni penjumlahan, pengurangan, perkalian, dan pembagian. Operasi penjumlahan digunakan oleh para pedagang untuk menghitung total harga pembelian barang. Dalam operasi penjumlahan terdapat dua strategi yang digunakan yakni dengan mengabaikan angka nol dan tanpa mengabaikan angka nol. Kedua strategi ini dilakukan oleh para pedagang demi kemudahan dalam menyelesaikan perhitungan, karena dalam berdagang hampir semua pedagang tidak menggunakan kalkulator.

Operasi pengurangan muncul ketika para pedagang menghitung uang kembalian dari hasil pembelian suatu barang oleh konsumen. Teknik pengurangan juga dengan menggunakan dua cara, sama halnya seperti pada proses penjumlahan yakni dengan mengabaikan angka nol dan tidak mengabaikan angka nol. Sedangkan operasi perkalian digunakan oleh para pedagang untuk menghitung total harga suatu barang apabila konsumen membeli satu jenis barang dalam jumlah banyak. Contohnya konsumen membeli sayur putih sebanyak 4 ikat dengan harga jual perikat adalah $R p$ 5.000, untuk mempermudah perhitungan maka narasumber menggunakan operasi perkalian dengan mengabaikan angka nol sebagai ribuan, ratusan ribu dan puluhan ribu yakni yakni $4 \times 5=$ 20 , sehingga konsumen harus membayar $R p 20.000$ dan operasi pembagian digunakan untuk menghitung besar keuntungan yang akan diperoleh dari hasil penjualan barang yang dibeli dari produsen dengan harga borongan. Contohnya seorang pedagang membeli sayur putih satu bedeng dengan harga borong adalah $R p 100.000$ untuk memperkirakan besarnya keuntungan ketika pedagang tersebut menjual kembali sayur tersebut di Pasar Tradisional Noemuti dengan harga per ikat adalah $R p 5.000$ maka para pedagang memanfaatkan operasi pembagian. Operasi pembagian ini juga bukan hanya digunakan oleh para pedang sayur namun digunakan oleh para pedagang ikan, pakian dan juga para pedagang lainnnya. 


\section{Range: Jurnal Pendidikan Matematika Vol. 3 No. 1 Tahun 2021 Dominikus Kou dkk}

Selain operasi hitung, bahasa memegang peranan penting dalam transaksi jual beli. Berdasarkan hasil wawancara dengan subjek $S 1$ diketahui bahwa bahasa yang digunakan dalam transaksi jual beli di Pasar Tradisional Noemuti ada dua jenis yakni Bahasa Indonesia dan Bahasa Dawan. Bahasa Indonesia digunakan apabila dalam transaksi jual beli para pedagang ataupun konsumen tidak mengerti dengan Bahasa Dawan, Sedangkan Bahasa Dawan akan selalu digunakan apabila para pedagang ataupun konsumen mengerti Bahasa Dawan.

Pada umumnya sebagian besar para pedagang di Pasar Tradisional Noemuti yang paham Bahasa Dawan tidak menyebut bilangan dalam Bahasa Indonesia namun mereka lebih cenderung menggunakan Bahasa Dawan.

Bilangan itu merupakan hasil dari menghitung banyaknya kumpulan benda. Cara mengitung bilangan menggunakan Bahasa Dawan dapat dilihat pada tabel berikut:

Tabel 1. Cara Menghitung Bilangan Menggunakan Bahasa Dawan

\begin{tabular}{|c|c|}
\hline Bahasa Indonesia & Bahasa Dawan \\
\hline 1 (Satu) & Mese \\
\hline 2 (Dua) & $\mathrm{Nua}$ \\
\hline 3 (Tiga) & Tenu \\
\hline 4 (Empat) & $\mathrm{Ha}$ \\
\hline 5 (Lima) & Nim \\
\hline 6 (Enam) & $\mathrm{Ne}$ \\
\hline 7 (Tujuh) & Hitu \\
\hline 8 (Delapan) & Fanu \\
\hline 9 (Sembilan) & Sio \\
\hline 10 (Sepuluh) & Bo'es \\
\hline 11 (Sebelas) & Bo'esam mese \\
\hline 12 (Dua Belas) & Bo'esam пиа \\
\hline$\ldots$ & $\cdots$ \\
\hline 20 (Dua puluh) & Bo’nua \\
\hline 21 (Dua Puluh Satu) & Bo'nua mese \\
\hline$\ldots$ & $\ldots$ \\
\hline 30 (Tiga Puluh) & Bo’tenu \\
\hline
\end{tabular}




\begin{tabular}{cc}
\hline 90 (Sembilan Puluh) & Bo'sio \\
\hline 100 (Seratus) & Natun mese
\end{tabular}

Berdasarkan hasil penelitian yang telah dilakukan dengan menggunakan triangulasi teknik pengumpulan data, peneliti melakukan analisis data berupa analisis domain, analisis taksonomi, analisis komponensial dan analisis tema budaya. Pada tahap analisis domain peneliti menemukan adanya aktivitas mengelompokkan, aktivitas menghitung dan aktivitas membilang yang dilakukan oleh para pedagang di Pasar Tradisional Noemuti Kabupaten Timor Tengah Utara. Hal ini sesuai dengan yang dijelaskan oleh Indryani (2018:25-26) mengenai aktivitas mengelompokkan, aktivitas menghitung dan aktivitas membilang, bahwa aktivitas mengelompokkan merupakan kegiatan mengumpulkan barang berdasarkan jenisnya, sedangkan aktivitas menghitung merupakan aktivitas yang sering ditemukan beberapa konsep matematika seperti penjumahan, pengurangan, perkalian dan pembagian dan aktivitas membilang berhubungan dengan bentuk pertanyaan "berapa banyak". Unsur-unsur yang menjadi pembentuk aktivitas membilang dapat menggunakan media lidi, daun, batu, atau bahan alam lainnya secara tradisional. Selain itu aktivitas membilang juga dapat dibentuk dari gerakan atau pukulan. Aktivitas membilang umumnya menunjukkan aktivitas penggunaan dan pemahaman bilangan ganjil dan genap serta lainnya.

Pada tahap analisis taksonomi domain mengelompokkan ditemukan pada pengemasan barang dagang sedangkan domain menghitung ditemukan pada penentuan harga jual dan interaksi sosial serta domain membilang ditemukan pada interaksi sosial. Selanjutnya, pada tahap analisis komponensial domain mengelompokkan ditemukan pada pengemasan barang dagangan dengan cara menumpuk dan menggantung berdasarkan jenisnya sedangkan domain menghitung ditemukan pada perhitungan jumlah biaya produksi dengan keuntungan yang diinginkan pedagang, perhitungan total harga pembelanjaan barang yang tidak sejenis, perhitungan uang kembalian, perhitungan total harga pembelanjaan barang yang sejenis, perhitungan biaya pemotongan harga terhadap penjualan suatu barang (diskon) dan perhitungan besar keuntungan yang diperoleh dari hasil penjualan barang, serta domain membilang ditemukan pada penyebutan bilangan menggunakan Bahasa Dawan.

Pada eksplorasi budaya dan aktifitas pada pasar trasional ditemukan konsep - konsep dan prinsip matematika seperti konsep himpunan, konsep penjumlahan, konsep pengurangan, konsep perkalian, konsep pembagian, konsep bilangan kardinal, konsep diskon dan prinsip perbandingan serta prinsip persamaan linear. Hasil penelitian berupa eksplorasi konsep-konep matematika tersebut sejalan dengan hasil eksplorasi yang sudah ada di Kabupaten TTU, konsep matematika pada rumah tradisional ume kbubu dan uem le'u (Tlonaen \& Deda, 2021; Funan \& Mamoh, 2019).

\section{Simpulan dan Saran}

Simpulan

Berdasarkan paparan pada hasil dan pembahasan peneliti menyimpulkan bahwa aktivitas etnomatematika yang terdapat di Pasar Tradisional Noemuti Kabupaten Timor Tengah Utara antara lain:

1. Aktivitas Mengelompokkan

Aktivitas mengelompokkan merupakan kegiatan mengumpulkan barang berdasarkan jenisnya. Berdasarkan defenisinya, aktivitas mengelompokkan nampak dalam aktivitas menumpuk dan menggantung barang dagangan berdasarkan jenisnya. Konsep matematika yang terdapat pada aktivitas Mengelompokkan adalah konsep himpunan.

2. Aktivitas Menghitung

Aktivitas menghitung merupakan aktivitas membilang yang terdirimenjumlahkan, mengurangi, mengali, danmembagi. Aktivitas menghitung ini nampak pada beberapa aktivitas yang dilakukan oleh para pedagang di Pasar Tradisional Noemuti yakni sebagai berikut:

a. Menghitung jumlah biaya produksi dengan keuntungan yang diinginkan oleh para pedagang.

Konsep matematika yang terkandung adalah konsep pembagian. 


\section{Range: Jurnal Pendidikan Matematika Vol. 3 No. 1 Tahun 2021 Dominikus Kou dkk}

b. Menghitung total harga pembelian suatu barang. Konsep matematika yang terkandung adalah konsep penjumlahan. Selain konsep penjumlahan, dalam aktivitas ini juga ditemukan prinsip matematika yakni prinsip persamaan linear.

c. Menghitung uang kembalian. Konsep matematika yang terkandung adalah konsep pengurangan.

d. Menghitung biaya pemotongan harga terhadap penjualan suatu barang. Konsep matematika yang terkandung adalah konsep diskon. Selain konsep diskon, dalam aktivitas ini juga ditemukan prinsip perbandingan.

3. Aktivitas Membilang

Aktivitas membilang berhubungan dengan bentuk pertanyaan "berapa banyak". Aktivitas ini umumnya merujuk pada penggunaan dan pemahaman bilangan ganjil dan genap. Aktivitas membilang nampak pada penyebutan 1 ikat sayuran dengan menggunakan Bahasa Dawan adalah Futu Mese, dua ikat sayuran disebutnya dengan Futu Nua, tiga ikat sayuran disebut dengan Futu Tenu, dan seterusnya. Selain penyebutan satu ikat sayur, ada penyebutan untuk 1 tumpuk sayur dengan menggunakan bahasa dawan yaitu tupu mese, dua tumpukan sayur disebut tupи пиа, dan seterusnya. Konsep matematika yang terdapat pada aktivitas membilang adalah konsep bilangan kardinal

Konsep-konsep dan prinsip - prinsip matematika yang ditemukan dalam aktivitas para pedagang di Pasar Tradisioal Noemuti Kabupaten Timor Tengah Utara dapat diimplementasikan kedalam pembelajaran matematika di sekolah dalam bentuk pembuatan soal-soal matematika yang dapat diberikan kepada siswa untuk meningkatkan pemahaman terhadap materi yang diajarkan.

Saran

Berdasarkan kesimpulan yang diperoleh, maka peneliti menyarankan agar guru dapat menjadikan hasil eksplorasi aktivitas etnomatematika di Pasar Tradisioal Noemuti Kabupaten Timor Tengah Utara sebagai penerapan pembelajaran matematika kontekstual. Tujuannya adalah untuk menjembatani matematika dengan budaya lokal sebagai salah satu sumber pembelajaran yang konkret sehingga siswa terlibat aktif dalam kegiatan belajar mengajar.

\section{Daftar Pustaka}

Angriani, D. A. (2013). Keefektifan Model Kooperatif Tipe Tai Dengan Pendekatan Realistik Dalam Pembelajaran Sistem Persamaan Linear Dua Variabel Kleas VIII SMP Negeri 4 Sinjai Utara. Jurnal Matematika Dan Pembelajaran (MAPAN), 57.

Amsikan, S. \& Nahak, S. (2017). Hubungan Konsep Ruang Ume Kbubu Desa Kaenbaun Kabupaten Timor Tengah Utara Dengan Konsep Geometri. KNPMP II: Program Studi Pendidikan Matematika Fakultas Keguruan dan Ilmu Pendidikan Universitas Muhammadiyah Surakarta

D'Ambrosio, U. (1985). Ethnomathematics And Its Place In The History And Pedagogy Of Mathematics For The Learning Of Mathematic.

Funan, F.X. \& Mamoh. (2019). Eksplorasi Etnomatematika Uem Le'u Insana dalam Kaitannya dengan Konsep Geometri. RANGE: Jurnal Pendidikan Matematika, 1 (1), (pp. 87-91).

Indiyani, S. (2018). Eksplorasi Etnomatematika Pada Aksara Lampung. Skripsi,(pp. 25-26).

Supriadi, Arysetyawan, A., \& Tiurlina. (2016). Mengintegrasikan Pembelajaran Matematika Berbasis Budaya Banten Pada Pendirian SD Laboratorium UPI Kampus Serang. Jurnal Mimbar Sekolah Dasar, 2.

Suwarsono, M. Y. (2019). Eksplorasi Aspek Etnomatematika pada Rumah Adat Kampung Sawu Nusa Tenggara Timur. Prosiding Sendika.

Turmudi. (2017). Apa Mengapa Dan Bagaimana Implementasi Dalam Pembelajaran Matematika Dalam Kelas. Seminar Nasional Matematika (2 ${ }^{\text {nd }}$ Senatik) Program Studi Pendidikan $\quad$ FPMIPATI Universitas PGRI Semarang. Semarang: Prosiding. 
Tlonaen, M.A. \& Deda Y.N. (2021). Exploration Ethnomathematics on Traditional House Ume Kbubu in North Central Timor Districts. Journal of Physics: Conference Series 1776 (1), 012016. 